ELORE (ISSN 1456-3010), vol. $16-2 / 2009$.

Julkaisija: Suomen Kansantietouden Tutkijain Seura ry.

[http://www.elore.fi/arkisto/2_09/ajankoht_hytonen_niskanen_2_09.pdf]

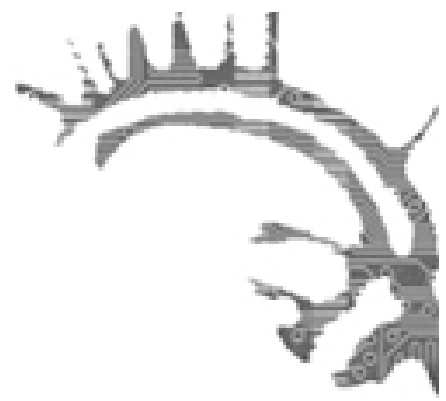

\title{
Ajankohtaista
}

\section{PohjOISMAISTA YHTEISTYÖtä TUTKIMUKSEN RAKENNUSKIVILLÄ}

Byggstenar - Substances. Rethinking the material, the visual and the narrative in culture. The 31 st Nordic Ethnology and Folklore conference Helsingissä 18.-22.8.2009

\section{Kirsi-Maria Hytönen ja Heli Niskanen}

Helsingin yliopiston päärakennus toimi pohjoismaisten etnologien ja folkloristien kohtaamispaikkana elokuussa 2009. Konferenssin teemana olivat kulttuurien peruskivet - elementit ja rakennelmat sekä materiaalisilla, visuaalisilla että narratiivisilla tasoilla. Aiheita käsiteltiin viiden päivän ajan 22 eri työryhmässä ja plenary-luennoilla.

\section{LUENTOJEN JA TYÖRYHMIEN ANTIA}

Etnologian professori Lena Gerholm (Tukholman yliopisto) aloitti ensimmäisen konferenssipäivän puhumalla etnologien ja etnologian rooleista tulevaisuuden rakentamisessa. Gerholm korosti, että etnologia tutkii isoja, yhteiskunnallisesti tärkeitä asioita. Tutkijoiden täytyy tehdä itsensä tarpeellisiksi, mutta on muistettava samalla myös nauttia työstään. Luennon jälkeen pohdittiin, mikä on etnologian rooli esimerkiksi historian rinnalla, ja Gerholm huomautti tieteiden välisen yhteistyön tärkeydestä.

Folkloristiikan professori Lotte Tarkka (Helsingin yliopisto) luennoi kalevalamittaisesta runoudesta Vienan Karjalassa. Tarkka pohti aineiston konteksti- ja käyttötietojen puutteen ongelmallisuutta ja esitteli metodologisia keinoja näiden ratkaisemiseksi. Hän kertoi myös eeppisen maailman runouden teemoista, jotka heijastivat kulttuurin kategorioita ja rajoja sekä loivat niiden kautta identiteettejä ja toiseutta. Lotte Tarkan huomio aineistostaan pitää mielestämme paikkansa myös tieteenalojemme kohdalla: dialogi menneen kanssa on orientoitumista tulevaisuuteen. 


\section{Kirsi-Maria Hytönen ja Heu Niskanen}

Tiistai jatkui työryhmien tapaamisilla ja illalla yliopiston vastaanotolla, jossa saimme tervehtiä pohjoismaisia kollegojamme vapaamuotoisemmin hyvän ruoan parissa.

Valitettavasti keskiviikon luennoitsija T. B. Shchepanskaya (St. Petersburg State University) oli joutunut perumaan osallistumisensa, mutta hänen tilallaan kuultiin tutkija Tuomas Palosen esittely Semanttisesta Kalevalasta. Kiinnostavaan projektiin voi käydä tutustumassa sen verkkosivuilla osoitteessa <http://www.seco.tkk.fi/applications/ kulttuurisampo/kalevala/> - tässä Eloren numerossa on myös aihepiiriä käsittelevä artikkeli.

Keskiviikkona työryhmätyöskentely pääsi kunnolla käyntiin ja keskustelu oli vilkasta. Esimerkiksi Pia Olssonin (Helsingin yliopisto) ja Mari Hatakan (Helsingin yliopisto) vetämässä työryhmässä Ideas and ideologies in the search of knowledge keskusteltiin historian aaveiden esiin kaivamisesta ja niiden kohtaamisesta. Mitä tehdä, kun aineistosta löytyy vaikeasti käsiteltäviä ajatuksia tai käsityksiä? Esimerkiksi kansallistunteen rakentamiseen on monia erilaisia tapoja, jotka tutkijan on huomioitava. Työryhmässä keskusteltiin myös nimen merkityksestä oppiaineen identiteetille - Suomessakin voi opiskella sekä kansatiedettä että etnologiaa.

Materialitetens sammenfiltringer -työryhmän puheenjohtajat Tine Damsholt ja Lene Otto (Kööpenhaminan yliopisto) sekä Liv Emma Thorsen ja Brita Brenna (Oslon yliopisto) halusivat pohtia materian sijaan materialisoitumista: luonnon ja kulttuurin sekä toisaalta materiaalisen ja sosiaalisen yhteen kietoutumisia. Esitykset lähestyivät tätä teemaa hyvin erilaisten empiiristen tutkimuskohteiden kautta - esitelmiä kuultiin niin museoesineistöstä, elinsiirroista, koululaukuista, valmisvaatteista kuin jopa turskasta.

Torstaiaamu alkoi odotetun yhdysvaltalaisen professorin Amy Shumanin (Ohio State University) plenary-luennolla. Hän kertoi kenttätyöstään Italiassa, jossa hän perehtyi marmorinveistäjien työhön, ammattitaitoon ja kulttuuriin. Hän pohti menneisyyden representoitumista sekä käsityötaidon ja -tiedon ruumiillistumista marmoriveistoksissa. Shumanin luennon yhteydessä keskusteltiin esimerkiksi tietotaidon ja perinteiden siirtymisen jatkuvuuksista ja katkoksista.

Amy Shuman osallistui luentonsa jälkeen kommentoijana työryhmään The Written in the Oral - the Oral in the Written, jonka puheenjohtajina toimivat Tuulikki Kurki (Joensuun yliopisto) ja Kirsti Salmi-Niklander (Helsingin yliopisto). Työryhmässä keskusteltiin suullisen ja kirjallisen perinteen suhteesta, vallasta ja auktoriteetista sekä niiden kietoutumisesta suullisiin ja kirjallisiin aineistoihin. Esitelmien kautta keskustelu kulki kirjallisen aineiston kääntämisen vaikeudesta kirjallisen ja suullisen aineiston metodiseen käyttöön. Työryhmässä pohdittiin myös esimerkiksi historian ja muistin, toisaalta myytin ja historian suhdetta. Suullisen ja kirjallisen taidon suhde todettiin toisiaan ylläpitäväksi.

Taina Kinnusen (Oulun yliopisto) työryhmä Life history as an embodied memory käsitteli ruumiillistumista erityisenä kiinnostuksen kohteenaan aistit ja kosketus. Ryhmässä pohdittiin esimerkiksi koulunkäyntiä ruumiillisena kokemuksena. Muistoissa koulu voi näyttäytyä ruumiillisten kokemusten kautta, ja etenkin ensimmäinen koulupäivä on monilla jäänyt elävästi mieleen erilaisina tuntemuksina. Keskustelussa havaittiin myös, miten syöpäkertomuksissa toistuvat usein ruumiilliset kertomuksen elementit, 
ruumiin eri osat saavat erilaisia painoarvoja ja ruumiinkuva muuttuu.

Perjantain luennoitsijakaksikosta ensimmäisenä oli vuorossa Mikkel Venborg Pedersen (National Museum, Tanska), joka puhui ihmisen ja materian suhteesta. Materia ja esineet ovat kulttuurin selkeimpiä rakennuskiviä, ja siksi tarvitsemme empiiristä tietämystä aiheesta. Esimerkiksi vanhoja esineitä ja niiden käyttöä ja merkityksiä voi olla vaikea ymmärtää, jolloin on helppo sortua esittämään oletuksia esineiden ulkonäön perusteella. Myös keskustelussa luennon jälkeen tuotiin esiin materiaalisen aspektin tarpeellisuutta kulttuurien tutkimuksessa.

Folkloristiikan professori Anne Eriksen (Oslon yliopisto) heijasti museolaitosta, museoesineiden merkityksiä ja näiden muutoksia yhden sikarirasian kautta. Martiniquen saarella vuonna 1902 tapahtuneen tulivuorenpurkauksen tuhkaa sisältäneen rasian vaiheet eri tavoin luokiteltuna ja järjesteltynä osaksi museokokoelmia toi esiin, miten esineet voidaan valjastaa kertomaan eri asioista ja miten niiden kautta voidaan tuoda menneisyyttä eri tavoin lähelle nykypäivää. Museoesineet voivat kertoa meille paljonkin, mutta ne voidaan myös laittaa kertomaan halutuista asioista.

\section{VILKASTA KESKUSTELUA}

Perjantai-iltapäivän ja samalla konferenssin virallisen osuuden päättäneessä loppupaneelissa puheenjohtajana toimi professori Anna-Maria Åström (Åbo Akademi) ja keskustelijoina Pertti Anttonen (Helsingin yliopisto), Anne Eriksen, Amy Shuman, Laura Stark (Jyväskylän yliopisto), Lotte Tarkka ja Mikkel Venborg Pedersen. Loppupaneelin keskustelu liikkui monenlaisissa teemoissa. Esimerkiksi Laura Stark nosti keskusteluun kulttuurien tutkimuksen pienten oppiaineiden rahoituksellisen tilanteen ja totesi, että meidän on opittava pärjäämään kilpailussa "kovempien" aineiden kanssa. Mikkel Venborg Pedersen myös rohkaisi etnologeja ja folkloristeja uskomaan itseensä enemmän ja unohtamaan epävarmuuden. Mitä enemmän epävarmuudesta puhutaan, sitä epävarmemmalta oman tieteenalan asema tuntuu. Paneelissa pohdittiin myös kulttuurien tutkimuksen varsinaista kohdetta: mitä osaa kulttuurista me tutkimme? Amy Shuman pyysi eri kieliä puhuvia läsnäolijoita kertomaan, miten "everyday life" kääntyy pohjoismaisille kielille. Keskustelusta nousi esiin mielenkiintoinen kysymys: jos tutkimuskohteemme on arkipäivä tai ihmisten arki, niin emmekö me tutki juhlia ja pyhän viettoa lainkaan. Vilkas keskustelu osoitti, että käsitteiden käyttötavat merkitsevät tieteenaloillamme hyvin paljon: niillä voi rajata tai avata tutkimuksen kenttää.

Paneelin lopussa keskusteluun nostettiin vielä esiin kysymys etnologian ja folkloristiikan historiallisuudesta. Panelistit totesivat, että oppiaineemme ovat aina myös historiallisia, sillä historia ei ole vain menneisyyttä vaan näkökulma maailmaan sekä ymmärrystä siitä, että kaikki voi muuttua. Sosiaalinen muutoshan avautuu tutkimuksessa ajallisen ulottuvuuden kautta. Toisaalta myös lyhyen aikavälin ja nykypäivän tutkimus on tärkeää voidaksemme vastata etnologeille ja folkloristeille usein esitettyyn kysymykseen: minne olemme menossa?

Konferenssin väliajoilla keskusteltiin kielikysymyksestä pohjoismaisessa konferenssissa. Monet suomalaiset kokivat vaikeaksi erityisesti norjan- ja tanskankielisten 


\section{Kirsi-Maria Hytönen ja Heu Niskanen}

esitelmien seuraamisen. Toisaalta pohjoismaiset kielet ovat osa NEFKin konferenssiperinnettä. Tukevatko pohjoismaiset kielet tieteenalojemme pitkälti kansallista luonnetta vai onko englannin kieli avain tutkimuksemme kansainvälistymiseen? Keskustelu aiheesta varmasti jatkuu tulevaisuudessa.

Konferenssin järjestelyt toimivat erittäin hyvin. Saimme nauttia oheisohjelmassa esimerkiksi keskiviikkona järjestetystä retkestä Suomenlinnaan. Kaunis ilta ja maukas borssikeitto kruunasivat opastetun kierroksen. Myös tiistai-illan vastaanotto ja torstain illallinen Kaapelitehtaalla olivat onnistuneita. Halukkaille oli tarjolla lisäksi saunailta Lauttasaaressa perjantaina ja esimerkiksi Porvooseen suuntautuva risteilyretki lauantaina.

Jäämme mielenkiinnolla odottamaan seuraavaa NEFK-konferenssia, joka pidetään kolmen vuoden kuluttua Bergenissä.

Filosofian maisteri Kirsi-Maria Hytönen ja filosofian lisensiaatti Heli Niskanen valmistelevat väitöskirjojaan Jyväskylän yliopiston historian ja etnologian laitoksessa. 